\title{
Age estimation, corroboration and back-calculation of four-spot megrim (Lepidorhombus boscii) on the Porcupine Bank using otoliths
}

\author{
Jorge Landa *, Carmen Hernández \\ Instituto Español de Oceanografía, Centro Oceanográfico de Santander, Promontorio de San Martín s/n, 39080, Santander, Spain
}

\section{A R T I C L E I N F O}

\section{Keywords:}

Calcified structures

Fisheries

Growth

Northeast Atlantic

Survey

Year-class

\begin{abstract}
A B S T R A C T
Age and growth of four-spot megrim (Lepidorhombus boscii) at the Porcupine Bank, an important European demersal fisheries area, was estimated for the first time based on the analysis of 1334 otoliths. The state of the stock in the Celtic Seas (including the Porcupine Bank) and the northern Bay of Biscay (Div. 7.b-k and 8.a,b,d) has been recently assessed in ICES mainly based on survey abundance indices, but biological information for a forthcoming age-structured stock assessment process is required. In this study, age was estimated by counting the translucent bands (annuli) of the sagittal otoliths following internationally standardized protocols. Otoliths were obtained from specimens caught during five annual bottom trawl surveys (2008-2012) carried out at the Porcupine Bank. Consistency in age interpretation of four-spot megrim was demonstrated by analyzing the regularity of the distances of the annuli to the otolith's primordium and by the back-calculation of the annuli. The growth patterns obtained from direct otolith age estimation and from back-calculation were also compared. Age estimation was corroborated by tracking year-class abundance indices from the surveys. The strength of the yearclasses was well tracked in abundant first age groups, highlighting the very abundant 2008 year-class. Furthermore, the von Bertalanffy growth parameters by sex and for combined sexes were also estimated and compared with those from other stocks. The results obtained for these parameters in the combined sexes direct age estimation, their back-calculation and the combination of both methods $\left(L_{\infty}: 50.093 ; \mathrm{k}: 0.126 ; \mathrm{t}_{0}:-0.296\right)$ will allow the upcoming age-structured assessment of this stock and thus a suitable population management. The strength of the cohorts here obtained was compared with those from a previous study in the Iberian Atlantic (8.c, 9.a) stock and based on age estimates calculated with the same ageing criterion. The differences in demographic structure and cohort dynamics found between stocks support the requirement that each stock continues to be assessed based on its respective age estimates and length distributions.
\end{abstract}

\section{Introduction}

The four-spot megrim (Lepidorhombus boscii) is a pleuronectiform fish distributed in the North-East Atlantic, from the Northern British Isles to Western Sahara $\left(26^{\circ} \mathrm{N}\right)$, and in the Mediterranean, at depths up to $800 \mathrm{~m}$ (Whitehead et al., 1986). The four-spot megrim from Porcupine Bank (ICES Div. 7.b,c,k) belongs to the "Celtic Sea, west of Ireland, and northern Bay of Biscay stock" (Div. 7.b-k and 8.a,b,d) (ICES, 2018). The state of this stock has been preliminarily assessed in ICES (International Council for the Exploration of the Sea) mainly based on survey abundance indices, but no model assessment has been used. However, biological information, such as age structure and growth, is not available but is required for a forthcoming age-structured stock assessment process, aimed at gaining a better knowledge and management of this resource. $L$. boscii in 7.b-k, 8.a,b,d is caught in a mixed fishery, predominantly by Spanish, Irish, French and UK demersal fleets, with annual landings of around $1200 \mathrm{t}(\sim 12 \mathrm{M} €)$ in 2017-18, more than $70 \%$ of which are Spanish (ICES, 2019).

Determining age and growth in fish is essential to understand their population life traits and assessing stock status using age-based models that include their population structure and mortality (Panfili et al., 2002). Otoliths, located in the inner ear of fish and composed of calcium carbonate and protein which is deposited at different growth rates throughout their lifetime, are one of the most commonly used calcified structures for age estimation (Casselman, 1987). The calcium carbonate-protein deposition process leaves periodical (annual or daily) opaque and hyaline zones in otoliths, mainly in temperate regions, which can be used to estimate annual age based on their seasonal

\footnotetext{
* Corresponding author.

E-mail address: jorge.landa@ieo.es (J. Landa).
} 
formation.

Fish growth varies temporarily and geographically. Updated, accurate and precise age and growth information in each distribution area of a species is required to estimate catches at age and year required for stock assessment, thus allowing to obtain more accurate estimates of fishing mortality, biomass and recruitments. To avoid biased results in the stock assessment process, the information on age and population growth must be consistent and validated or corroborated by some alternative method to the direct age estimation of calcified structures.

Several studies have analyzed the age and growth of four-spot megrim, but mainly in areas further south (Iberian Atlantic stock and Mediterranean area) than the one studied here, where the species is most abundant (see review in Cengiz et al., 2013; Landa and Fontenla, 2016). We only have knowledge of three growth studies in the 7.b-k, 8.a,b, d stock: the preliminary work of Dawson (1991) in the Celtic Sea (ICES Div. 7.h,j), that of Robson et al. (2000) in west Ireland (Div. 7.b), and that of Landa et al. (2002) in the northern Bay of Biscay (Div. 8.a,b), showing growth parameters by sex in the first and last study, attending to its sexual dimorphism. Regarding the 7.b-k and 8.a,b,d four-spot megrim stock, robust and updated growth information in some areas is still required, since only the mentioned study of Robson et al. (2000) presented parameters of combined sexes that can be directly applied in age-structured stock assessments, and it was based on a reduced number of samples (150 otoliths) and data from the 90's. To our knowledge, there is no other study of four spot megrim growth on the Porcupine Bank, an over $40,000 \mathrm{~km}^{2}$ relevant European fishing area, targeting mainly bottom species, located $150-200 \mathrm{~km}$ off the western Irish coastline.

The age and growth parameters of commercially important species contribute to understanding the biology of specific populations and their contribution to the ecosystem. Four-spot megrim stock biology at the Porcupine Bank has only been studied scarcely, but its state of exploitation is of great interest if the stock is to be assessed and managed properly. However current estimations considering only growth parameters in this stock, but lacking evidence of ageing validation or corroboration, are not appropriate if this biological information is to be provided with guarantees for an adequate and accurate stock assessment process. Thus, the present study is the first to: i) investigate growth patterns of four-spot megrim at the Porcupine Bank, based on the analysis of otolith (sagittae) annuli; ii) conduct a back-calculation of the annuli, showing consistency in age interpretation; iii) corroborate (or indirectly validate) growth patterns by tracking cohorts in the available time-series obtained in Porcupine Bank surveys. Furthermore, the growth parameters and performance indices obtained by direct age estimation and back-calculation were also compared with those shown by other authors in European waters, and are currently available for the forthcoming first age-structured assessment process of this stock.

\section{Material and methods}

\subsection{Samples}

Five annual surveys, following coordinated IBTS (International Bottom Trawl Surveys) protocols (ICES, 2010a) were carried out at the Porcupine Bank from $11^{\circ}$ to $15^{\circ} \mathrm{W}$ and $51^{\circ}$ to $54^{\circ} \mathrm{N}$ (in ICES Div. 7.b,c,k), covering a depth range of $180-800 \mathrm{~m}$ (Fig. 1). They were performed in September 2008-2012, by the research vessel "Vizconde de Eza". The elliptical Porcupine Bank is a part of the continental shelf, although it forms a structure similar to a seamount due to its geographical shape, bathymetric configuration and oceanographic circulation, providing an important mechanism for the retention of pelagic eggs and larvae of various marine species (White et al., 1998; Mohn et al., 2002). It also presents topographic and background sediment differences between its northwestern and southeastern parts (Velasco et al., 2008). The survey sampling design was a random stratified proportional-to-strata area based on five strata resulting from two geographic sectors (north; south), three depth strata $(<300 \mathrm{~m} ; 301-450 \mathrm{~m} ; 451-800 \mathrm{~m})$ and considering that there are no trawlable grounds shallower than $300 \mathrm{~m}$ in the southern sector (Velasco et al., 2008...; ICES (2010b). The allocation of samples within strata (Fig. 1) was performed each year using a buffered random sampling procedure (Kingsley et al., 2004).

Total lengths of 1464 four-spot megrims were measured on board to the nearest centimetre below and their otoliths collected (Table 1).

Table 1

Number of four-spot megrims sampled by annual survey.

\begin{tabular}{lllllll}
\hline Year & 2008 & 2009 & 2010 & 2011 & 2012 & Total \\
\hline Number & 282 & 286 & 323 & 273 & 300 & 1464 \\
\hline
\end{tabular}
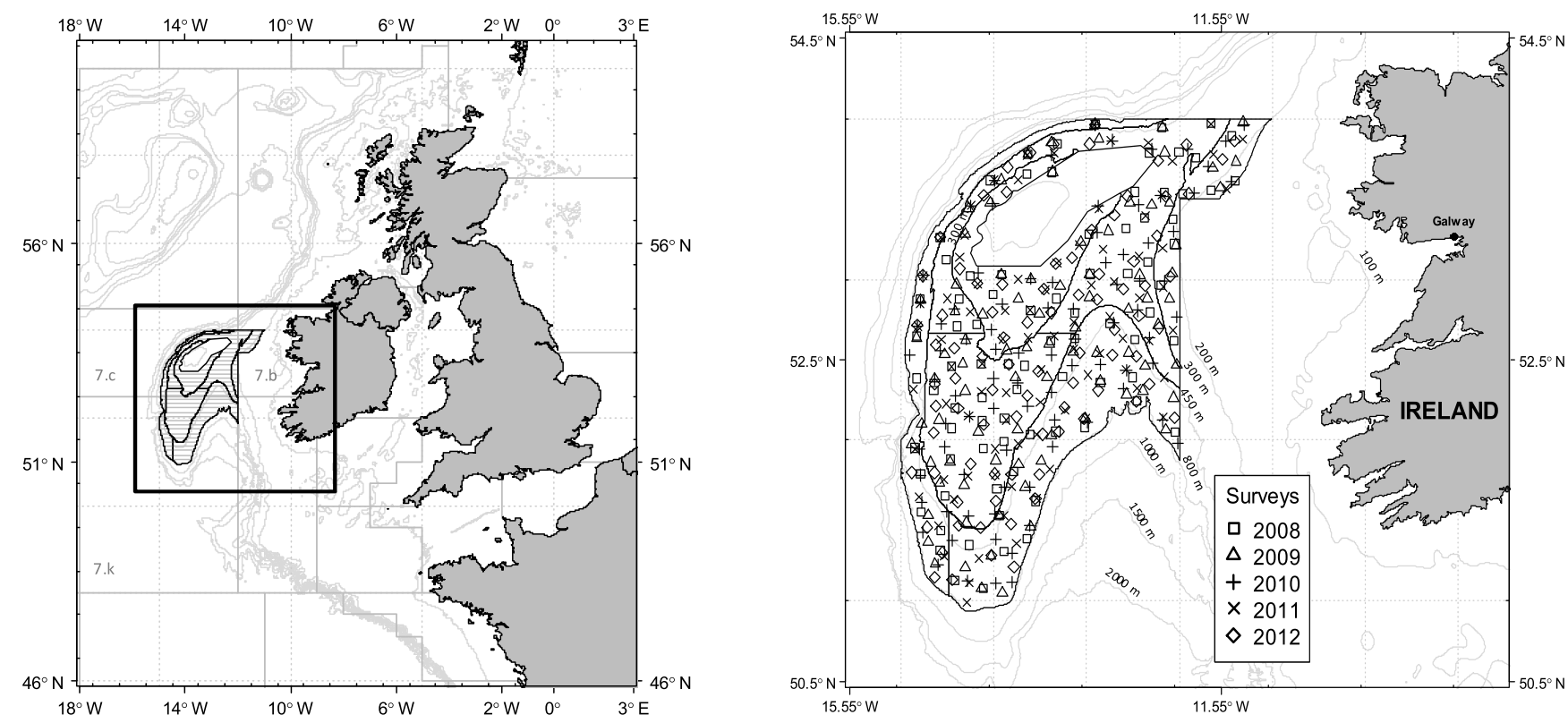

Fig. 1. Location of the Porcupine Bank and the area sampled (in ICES Div. 7.b,c,k) (left panel), including the hauls performed during the time-series of surveys (right panel). 


\subsection{Direct age estimation}

As in other four-spot megrim ageing studies, both whole sagittal otoliths per individual were observed immersed in water, under a stereomicroscope (20x magnification) with reflected light, and a black background (Fuertes, 1978; Bello and Rizzi, 1987; Santos, 1994; Robson et al., 2000; Landa et al., 2002; Landa et al., 2014). Age interpretation was performed following the internationally standardized criterion of Anon (1997), used in successive ICES ageing workshops and otolith exchanges of the congener L. whiffiagonis (Egan et al., 2004; Etherton, 2011; Gault, 2019), which is suitable for L. boscii given their high similarities. Age was estimated by interpreting and counting the well-defined translucent growth bands (annuli) observed in three main areas of the otoliths (Fig. 2), following the overall agreed scheme of otolith edge interpretation, and considering the 1st of January as the birthdate (Anon, 1997). All analyzed otoliths were obtained in September, the month in which usually the opaque band is growing at the otolith's edge (Fuertes, 1978; Vassilopoulou and Ondrias, 1999).

The age of almost all samples collected (89\%) in each annual survey was estimated, representing specimens of the whole range of captured sizes, up to a maximum of 10 individuals per $1 \mathrm{~cm}$ length range by survey. Otoliths were aged independently by two readers and those with disagreement in age estimations were examined again by both readers, a final agreed age being adopted. Otoliths whose ages were definitively uncertain were excluded from the analysis. Age was thus estimated for 1334 otoliths (Table 2), a mean number of 267 otoliths ranging from 3 to $54 \mathrm{~cm}$ in fish length, per survey. Almost all (94\%) the fish examined were sexed as male or female, but $6 \%$ ( 81 individuals) were undetermined. They were specimens $<13 \mathrm{~cm}$, mostly belonging to ages 0 and 1 . The female/male ratio (of sexed individuals) in the surveys, in age 1 was $55 / 45$. Therefore, for our analysis of growth by sex, this proportion was assumed and applied to assign undetermined individuals to females or males, in order to have length/age values in the estimation of parameters by sex. Thus, a total of 455 females and 879 males were studied.

Age-length keys (ALK) by sex and combined sexes were built per survey for 5 years in the time-series based on the pairs of length and estimated age values. Each ALK was applied to the respective stratified length distribution of the survey, obtaining their abundance indices and mean lengths at age. Mean lengths at age were estimated for those age groups with a minimal representative number of age estimates $(\geq 3)$ and with age estimates present throughout most of the length range corresponding to that age group in the ALK. Thus, certain old age groups

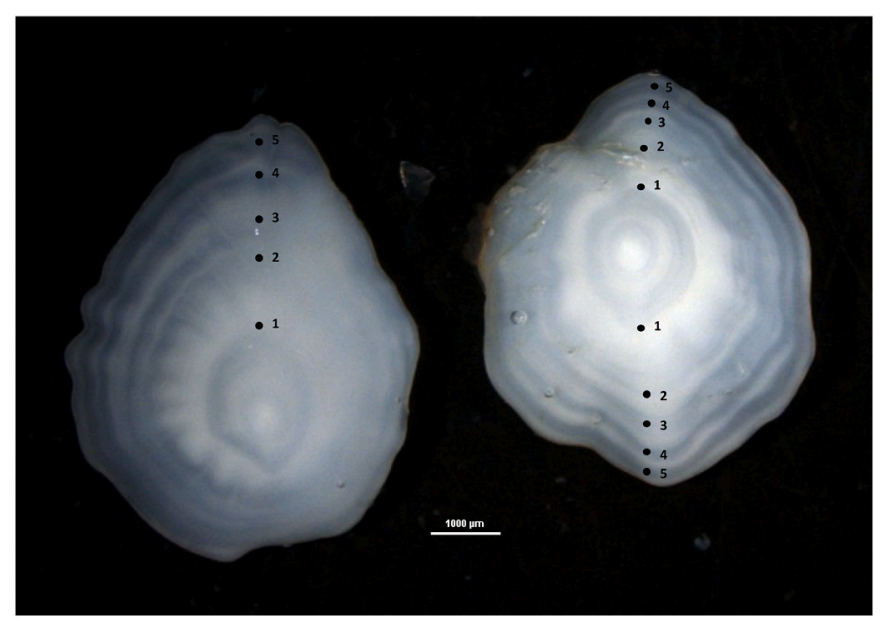

Fig. 2. Both sagittal otoliths of a four-spot megrim specimen caught in September and with an estimated age of 5 years. The three main otolith areas where the age is estimated, including the translucent growth increments considered as annuli, are shown.
Table 2

Overall mean lengths and standard deviations (SD) at age for the time-series for combined sexes of four-spot megrim, estimated as the mean value of the mean lengths at age and that of the SD of all years. The number of otoliths aged, coefficient of variation (CV) and annual growth rate at age are also showed.

\begin{tabular}{llllll}
\hline $\begin{array}{l}\text { Age } \\
\text { group }\end{array}$ & $\begin{array}{l}\text { Total } \\
\text { number }\end{array}$ & $\begin{array}{l}\text { Mean length } \\
(\mathrm{cm})\end{array}$ & $\begin{array}{l}\text { SD } \\
(\mathrm{cm})\end{array}$ & $\begin{array}{l}\text { CV } \\
(\%)\end{array}$ & $\begin{array}{l}\text { Growth rate } \\
(\mathrm{cm})\end{array}$ \\
\hline 0 & 23 & 4.6 & 0.3 & 7.3 & - \\
1 & 110 & 11.9 & 1.1 & 9.2 & 7.3 \\
2 & 129 & 15.9 & 1.5 & 9.6 & 4.0 \\
3 & 209 & 19.2 & 1.9 & 9.7 & 3.3 \\
4 & 182 & 22.4 & 2.1 & 9.5 & 3.1 \\
5 & 175 & 24.1 & 2.5 & 10.3 & 1.7 \\
6 & 161 & 27.2 & 2.9 & 10.5 & 3.2 \\
7 & 132 & 29.4 & 3.1 & 10.5 & 2.1 \\
8 & 107 & 32.0 & 3.7 & 11.5 & 2.6 \\
9 & 66 & 34.3 & 2.7 & 7.9 & 2.3 \\
10 & 26 & 37.3 & 1.8 & 4.9 & 3.1 \\
11 & 9 & 39.4 & 1.9 & 4.9 & 2.0 \\
12 & 2 & - & - & - & - \\
13 & 3 & - & - & - & - \\
\hline
\end{tabular}

appearing in some surveys were not considered for the estimation of their respective mean lengths (Table 2).

\subsection{Back-calculation}

Images from the otoliths obtained with the stereomicroscope equipped with a digital camera, were examined with an image-analyser (NIS Elements v4.20.00). The radius of the right sagittal otolith was measured along the longitudinal axis in the posterior area, and the distances of all the translucent growth increments to the primordium of the otolith were also measured, along the same longitudinal axis. Fuertes (1978) showed the seasonality of annuli formation in this species in Atlantic waters, evidencing that the translucent edge is mostly predominant from November to April, while the opaque edge predominates during the rest of the year, April being the month when the formation of the translucent annulus finishes. Therefore, the back-calculated lengths in this study corresponded to fish lengths estimated around April.

To verify the regularity in annuli formation and to demonstrate the consistency in age interpretation, the measures of the considered annual growth increments were represented, expecting a unimodal distribution in the measurements in each annulus. Given the differential growth of this species, this was done separately for each sex.

The fish length and otolith radius relationship was estimated by sex using the 559 values available and following two models:

linear regression: $\mathrm{L}=\mathrm{a}+\mathrm{b} \mathrm{R}$

power regression: $\mathrm{L}=\mathrm{c} \mathrm{R}^{\mathrm{d}} ; \mathrm{L}^{\prime}=\mathrm{c}^{\prime}+\mathrm{d} \mathrm{R}^{\prime}$

Where $L$ is the total fish length when the specimen was caught (cm); $a, b$ are the parameters of the regression function; $R$ is the otolith radius when the specimen was caught $(\mu \mathrm{m}) ; L^{\prime}=\ln (L) ; c^{\prime}=\ln (c) ; R^{\prime}=\ln (R)$.

The BPH (Body Proportional Hypothesis) method, described by Whitney and Carlander (1956) and revised by Francis (1990), and the Fraser-Lee method (Fraser, 1916; Lee, 1920) were applied. Both methods provide useable back-calculated lengths (Ricker, 1992):

Fraser-Lee: $\mathrm{Li}=\mathrm{a}+(\mathrm{L}-\mathrm{a})(\mathrm{Ri} / \mathrm{R})$

Body Proportional Hypothesis $(\mathrm{BPH}): \mathrm{Li}=\mathrm{L}(\mathrm{a}+\mathrm{b} \mathrm{Ri}) /(\mathrm{a}+\mathrm{b} \mathrm{R})$

Where Li is the total fish length when otolith radius was $R i(\mathrm{~cm}) ; L$ is the total fish length when caught $(\mathrm{cm})$; Ri is the otolith radius of the $i$-th ring of the otolith $(\mu \mathrm{m}) ; R$ is the otolith radius when caught $(\mu \mathrm{m}) ; a, b$ are the $p a-$ rameters of the linear regression (1); when the power regression was used, $L^{\prime}$, $c$ ', $d$ and $R$ ' from (2) instead of $L, a, b$ and $R$ were used in (3) and (4).

After selecting the best-fitting fish length and otolith radius 
relationship, two scenarios were finally used:

- A: power L-otolith regression model (2) with the Fraser-Lee backcalculation equation (3);

- B: power L-otolith regression model (2) with the BPH backcalculation equation (4).

\subsection{Growth parameters and index}

The parameters of the von Bertalanffy growth function (VBGF) (von Bertalanffy, 1938) were estimated from both observed and back-calculated lengths at age, by applying a nonlinear regression using the Levenberg-Marquardt estimation method (SPSS 17.0).

$\mathrm{Lt}=\mathrm{L}_{\infty}\left(1-\mathrm{e}^{-\mathrm{k}\left(\mathrm{t}-\mathrm{t}_{0}\right)}\right)$

Where Lt is the mean length at age $t ; L_{\infty}$ is the mean asymptotic length; $k$ is the instantaneous growth coefficient; $t$ is the age and $t_{0}$ the age at which the mean length would be 0 .

To have a more accurate estimate of growth parameters, the estimated age values were transformed into "absolute age". The "absolute age" for a specimen was estimated as a function of the age estimated adding the capture season, namely, the proportional part of the year in which it was caught.

The growth performance index ( $\left.\Phi^{\prime}\right)$ (Pauly and Munro, 1984), a synthetic index of the VBGF growth that includes their inversely correlated $L_{\infty}$ and $k$ parameters, was used to compare growth patterns among studies. It was estimated as follows:

$\Phi^{\prime}=\log 10 \mathrm{k}+2 \log 10 \mathrm{~L}_{\infty}$

Where $L_{\infty}$ and $k$ are the parameters of the VBGF.

\subsection{Age slicing}

We also assessed if the growth parameters obtained from the age estimates could provide a reliable matrix of Abundance indices at Age and year $(\mathrm{AaA})$ in the available longer time-series of 18 years (2001-2018) of four-spot megrim length frequencies. The age slice method from the Length Frequency Distribution Analysis (LFDA) package (Kirkwood et al., 2001) was used to apply the growth parameters obtained from direct age estimation and back-calculation to the stratified length compositions of the surveys, being thus transformed into abundances by age. In this way, a new AaA matrix was obtained, and the standardized abundance proportions at age were estimated to check the cohorts' tracking over time.

\subsection{Tracking cohorts}

Two matrices of Abundance indices at Age and year (AaA) were obtained after applying: i) the ALK obtained in each survey (2008-2012) to their respective length distribution (LD), and ii) the age slice method to the whole time-series (2001-2018) of LDs. The AaA matrices were analyzed using their standardized abundance proportions at age, in which the cohorts tracking along the years could be checked. A correct tracking of the strength of the cohorts in the standardized abundance proportions of the age matrix, mainly those extremely abundant or scarce ones, is a first indicator of a non-biased age estimation criterion and the ability of the survey to track year-group strength.

The values of the correlation coefficients estimated over time between two consecutive ages from the same cohorts provide an indication of the consistency of cohort tracking by age range, and they were estimated as follows (Beare et al., 2003):

$\log \left(\mathrm{N}_{\mathrm{a}, \mathrm{y}}\right)$ vs. $\log \left(\mathrm{N}_{\mathrm{a}+1, \mathrm{y}+1}\right)$

Where $N$ is the abundance index; $a$ is the age; and $y$ is the year.

\section{Results}

\subsection{Mean lengths at age}

Different growth patterns by sex were observed, with higher growth rates by age in females, which is common in flatfish. Similar growth patterns were observed by direct age estimation and back-calculation, showing consistency in age interpretation (Fig. 3).

\subsubsection{Direct age estimation}

Age-length-keys (ALK) by sex (879 females and 455 males) and combined sexes were built for each annual survey from 2008 to 2012, using the length and age from otolith direct age estimations. The estimated age range was $0-11$ years in males and up to 13 years in females. Most of the individuals were young and the oldest age groups included a few specimens. Thus, half of the males captured were between 0 and 3 years old, while half of the females ranged between 0 and 5 years in age.

After applying each ALK to its respective LD, mean lengths and variability $(\mathrm{SD}, \mathrm{CV})$ at age for the time-series were estimated for sexes combined (Table 2). Mean lengths at age by sex were also estimated, showing values of $\sim 12 \mathrm{~cm}$ at age 1 , and diverging between sexes from that age group onwards, with values at age 8 of $\sim 28 \mathrm{~cm}$ and $\sim 33 \mathrm{~cm}$ for males and females, respectively (Fig. 3). The CVs resulted in similar values, close to $10 \%$, in most age groups, showing no remarkable inaccuracy in any specific age group (Table 2). Annual growth rates decreased with age in both sexes, with values at ages $1-2$ of $3.3 \mathrm{~cm}$ and $4.5 \mathrm{~cm}$ per year in males and females, respectively, and falling to rates of $\sim 1 \mathrm{~cm}$ and $\sim 3 \mathrm{~cm}$ per year, respectively, at ages 7-8 (Fig. 3).

The number of age estimates in each of the age groups in the 2008 year class observed in the constructed five annual ALKs (age 0 in 2008, age 1 in 2009, etc.), was the largest of the time-series comparatively for each age group, which may be a preliminary indication of a possible strong year class.

\subsubsection{Back-calculation}

Both models of regression analyzed, linear and power, in the fish length - otolith radius relationship were significant $(\mathrm{p}<0.001)$ and showed a good adjusted coefficient of determination $\left(\mathrm{r}^{2}\right)$ for both sexes, but the fit obtained with the power model was slightly better, being the only one used to estimate the back-calculated lengths (Fig. 4).

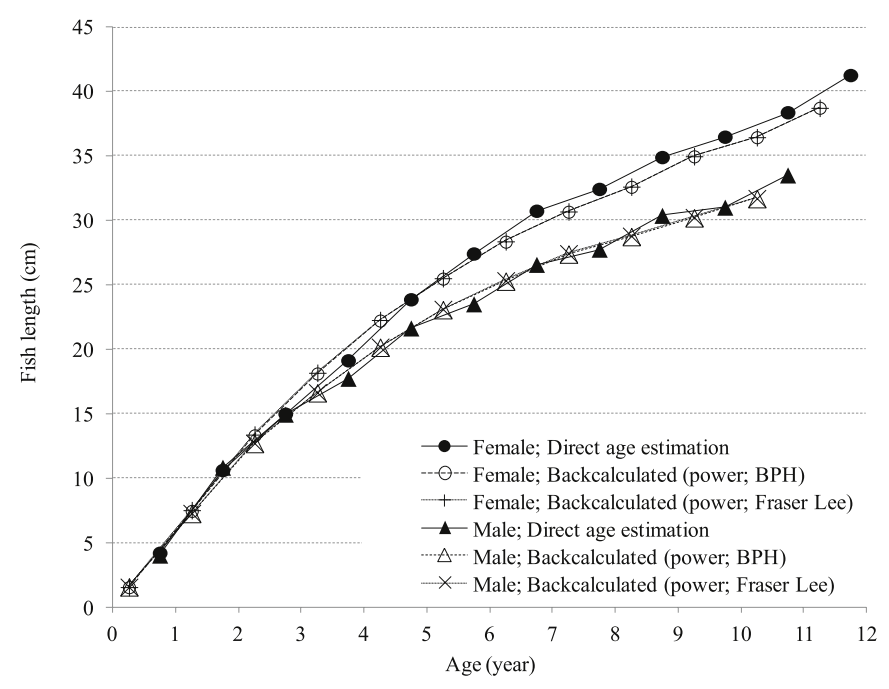

Fig. 3. Mean lengths at age by sex of four-spot megrim obtained by direct age estimation and back-calculation (BPH and Fraser-Lee methods), showing the differential sexual growth and the similarities between the values obtained by those methods. 


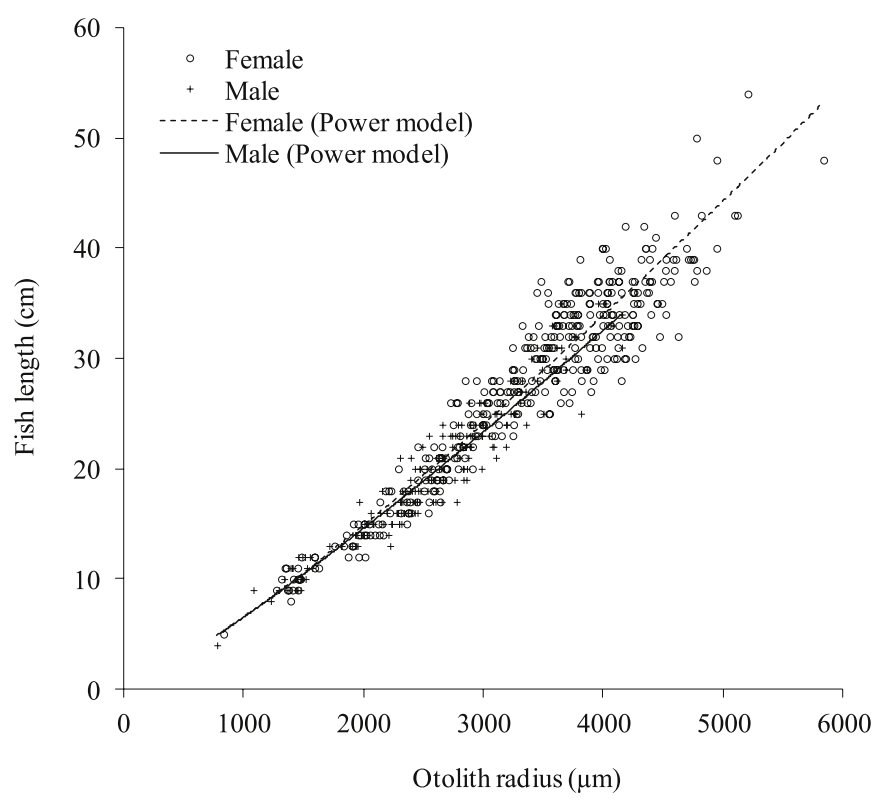

Fig. 4. Total fish length and otolith radius relationship using the power model for four-spot megrim by sex in Porcupine Bank.

- females: $\mathrm{L}=0.0017 \mathrm{R}^{1.1914}\left(\mathrm{r}^{2}=0.937\right)$

- males: $\mathrm{L}=0.0024 \mathrm{R}^{1.1614}\left(\mathrm{r}^{2}=0.929\right)$

The frequency distribution of all growth increments measured in the

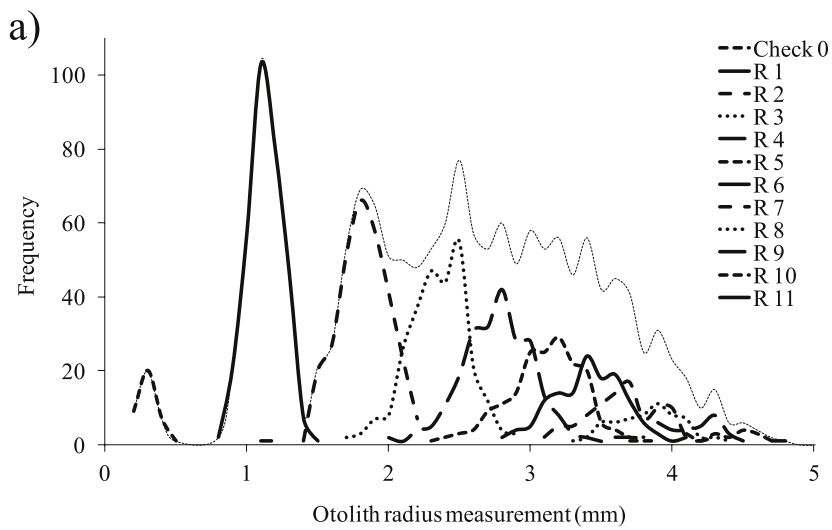

otoliths from the primordium showed a polymodal function in both sexes (Fig. 5). The pattern of deposition of each presumed annulus is mostly unimodal in both males and females, with an increase in their overlap in older ages. A modal length (otolith radius $<1 \mathrm{~mm}$ ) was also observed, corresponding to a presumed nonannual increment (check 0 ). This check is more frequently visible in otoliths from young four-spot megrim (which are also flatter), while it is more difficult to see in those of older individuals because thickening of the otoliths with age progressively hinders visualization of any growth increment.

Back-calculation allowed us to easily generate large amounts of information on growth of each otolith analyzed (several back-calculated lengths at age) compared to the direct age estimation (one length at age), contributing to estimate a more robust growth pattern. Thus, values of 1653 back-calculated lengths were obtained from 326 female otoliths and 615 from 164 male otoliths.

The back-calculated fish lengths obtained from the Fraser-Lee and BPH models were similar (Fig. 3), with only small differences $(<0.7 \mathrm{~cm})$ in some annuli. The number of back-calculated lengths obtained from the BPH model for each annulus, the mean values, standard deviation (SD), coefficient of variation (CV) and mean growth rates (for those annuli with $\geq 5$ values) by sex are shown in Table 3 . Decreasing annual growth rates by age were observed in both sexes, as well as decreasing CVs from the first 4 ages (CV: $11-14 \%$ ) to the last ones (around 4\%).

\subsection{Growth parameters and indices}

The VBGF growth parameters of four-spot megrim were estimated for combined sexes from: i) the individual lengths at age by direct age estimation, ii) those estimated from back-calculated lengths at age, and iii) those obtained by both methods together (Table 4). Similar growth performance indices ( $\left.\Phi^{\prime}\right)$ were obtained using the three approaches

b)

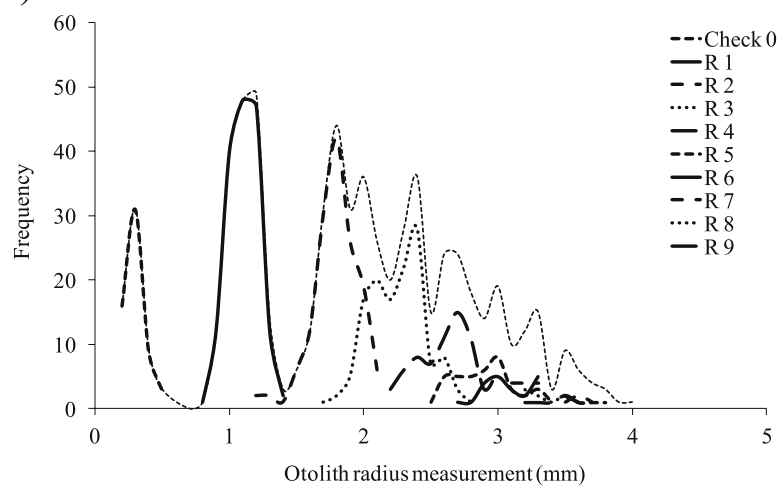

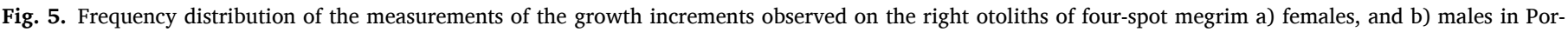

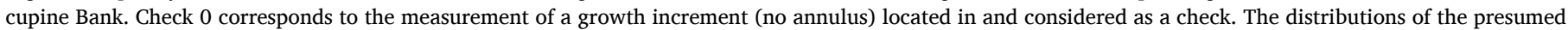
annuli are designated by a number (R1, R2, etc.) and the polymodal distribution of all measured growth increments is designated as R_all.

Table 3

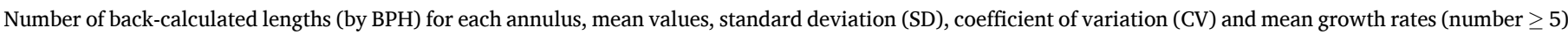
for four-spot megrim females and males in Porcupine Bank.

\begin{tabular}{|c|c|c|c|c|c|c|c|c|c|c|c|c|c|c|}
\hline & \multirow[t]{2}{*}{ Sex } & \multicolumn{13}{|c|}{ Annuli } \\
\hline & & 1 & 2 & 3 & 4 & 5 & 6 & 7 & 8 & 9 & 10 & 11 & 12 & 13 \\
\hline \multirow[t]{2}{*}{ Total number } & Females & 317 & 299 & 269 & 230 & 179 & 137 & 95 & 63 & 36 & 20 & 6 & 1 & 1 \\
\hline & Males & 162 & 146 & 131 & 70 & 39 & 24 & 18 & 11 & 8 & 5 & 1 & 0 & 0 \\
\hline \multirow[t]{2}{*}{ Mean length (cm) } & Females & 7.5 & 13.3 & 18.1 & 22.3 & 25.5 & 28.4 & 30.7 & 32.6 & 35.0 & 36.5 & 38.8 & - & - \\
\hline & Males & 7.3 & 12.7 & 16.6 & 20.2 & 23.1 & 25.3 & 27.4 & 28.8 & 30.2 & 31.7 & - & - & - \\
\hline \multirow[t]{2}{*}{$\mathrm{SD}(\mathrm{cm})$} & Females & 1.1 & 1.9 & 2.5 & 2.9 & 3.1 & 2.9 & 2.7 & 2.5 & 2.0 & 1.4 & 1.4 & - & - \\
\hline & Males & 0.9 & 1.5 & 2.2 & 2.3 & 1.8 & 1.8 & 1.5 & 1.5 & 1.2 & 1.2 & - & - & - \\
\hline \multirow[t]{2}{*}{ CV (\%) } & Females & 14 & 15 & 14 & 13 & 12 & 10 & 9 & 8 & 6 & 4 & 4 & - & - \\
\hline & Males & 12 & 12 & 13 & 11 & 8 & 7 & 6 & 5 & 4 & 4 & - & - & - \\
\hline \multirow[t]{2}{*}{ Mean growth rate $(\mathrm{cm})$} & Females & 7.5 & 5.9 & 4.8 & 4.1 & 3.3 & 2.9 & 2.3 & 1.9 & 2.4 & 1.5 & 2.3 & - & - \\
\hline & Males & 7.3 & 5.4 & 3.9 & 3.5 & 2.9 & 2.2 & 2.1 & 1.4 & 1.5 & 1.5 & - & - & - \\
\hline
\end{tabular}




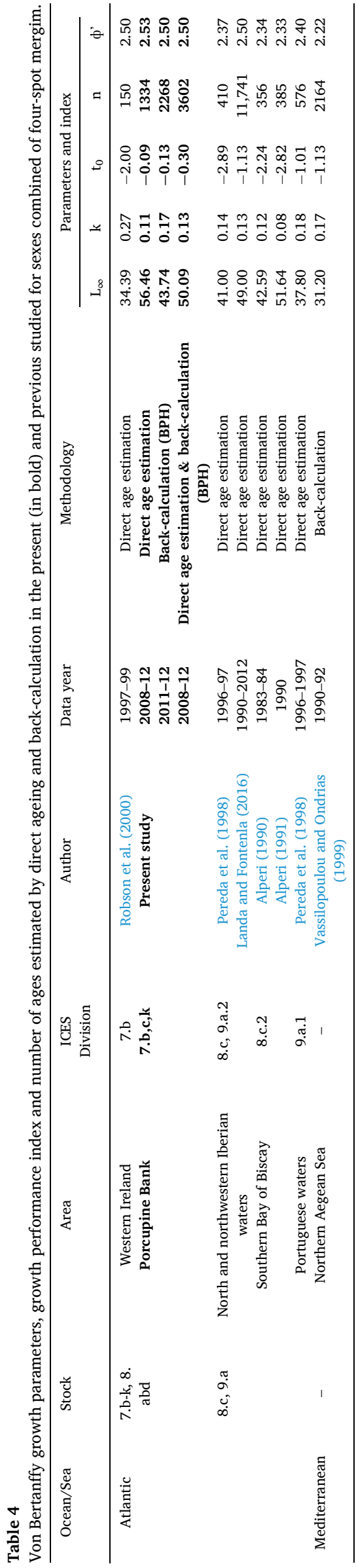

(2.50-2.53). Fig. 6 shows a compilation of the values obtained here and growth curves shown in other studies for combined sexes of this species. The growth parameters by sex show that females reach higher asymptotic lengths and lower $\mathrm{k}$ coefficients than males (Appendix Table A).

\subsection{Age slicing}

The age slicing method was applied to the LD of the 18 year survey time-series (2001-18) using the growth parameters estimated for combined sexes from direct age estimation and from back-calculation (Table 4). Both resulting matrices of standardized abundance proportions at age were similar. The bubble plot obtained from direct age estimation is shown in Fig. 7b.

\subsection{Tracking cohorts}

Two matrices of standardized Abundance proportions at Age and year (AaA) of four-spot megrim were analyzed:

Firstly, the AaA matrix obtained after applying the ALKs obtained for each survey (2008-2012) to their respective LDs, showed a satisfactory tracking of year-classes (Fig. 7a). The 2008 year-class was consistently the strongest in the time-series and that of 2007 was a weak year-class. The year-classes from 2003 to 2006 mainly showed abundances close to the average value of the time-series. These results corroborate the estimated annual growth pattern in otoliths and confirm that the age estimation criterion used was not biased. Although correlation coefficients between 0.65 and 0.80 were obtained when the abundance of two consecutive ages from the same year-classes in the first ages (0-1, 1-2, 2-3, 3-4) were compared, the correlations were not statistically significant ( $p>0.05$ ). Age groups 0 to 4 , and 0 to 5 represent $\sim 75 \%$ and $\sim 90 \%$, of the abundance in surveys, respectively. Older age groups are less abundant and more susceptible to variations in the age composition due to small variations in the number of individuals captured in certain years and, therefore, to greater difficulties in tracking cohorts in those older groups.

The AaA matrix obtained after applying age slicing to the overall time-series (2001-2018) of survey LDs using the growth parameters estimated for combined sexes from direct age estimation (Fig. 7b) was also analyzed. In general, certain cohorts (some corresponding to consecutive years) with abundances above (2008-11; 2001), and below (2014; 2005-06) the average, were observed. When analyzing data of only years $2008-12$ in Fig. $7 \mathrm{~b}$ (framed), which were the ones used to estimate the growth parameters, similarities with Fig. 7a were observed, especially when tracking the 2008 cohort, despite the lower accuracy of these estimations, compared to that shown in Fig. 7a obtained from direct age estimates.

\section{Discussion}

This study presents the growth patterns and demographic structure of four-spot megrim at the Porcupine Bank, and constitutes an important piece of knowledge on the biology of the species in its distribution area, and more specifically on its age, growth patterns and updated demographic structure. The year-classes tracking shown here allowed corroborating the age estimation and showing the preponderance of the abundant 2008 year-class. Consistency in age interpretation was also evidenced by the regularity of the annuli measurements and by the annuli's back-calculation. Our parameters are now available for the upcoming age-structured assessment process of the ICES 7.b-k, 8.a,b, d stock (Celtic Seas and northern Bay of Biscay).

\subsection{Growth pattern and parameters}

The sexual variation in growth patterns shown by this species is also common in other pleuronectiforms (Pauly, 1994). In this study, females showed larger mean lengths and growth rates at age, maximum lengths 


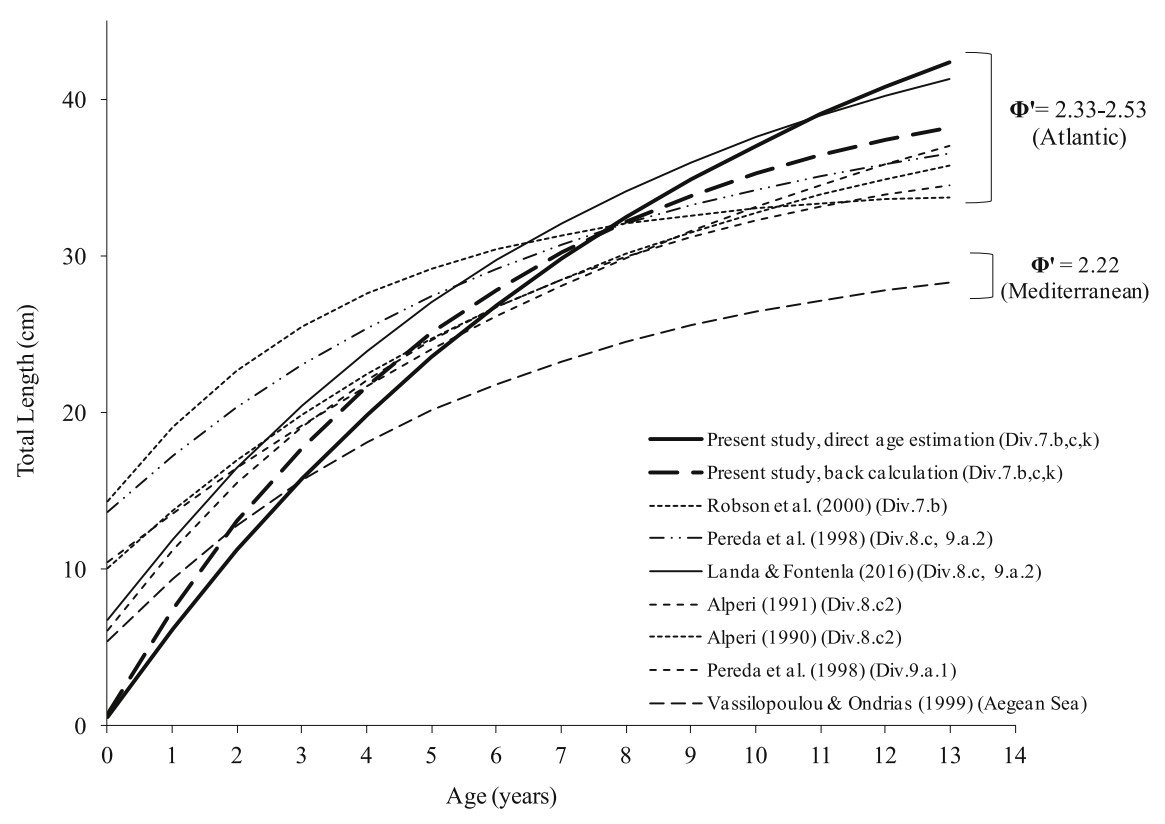

Fig. 6. Von Bertalanffy growth curves for combined sexes obtained from age estimation and by back-calculation of four-spot megrim in the present study and those from previous studies throughout its distribution area. The range of growth performance indices ( $\left.\Phi^{\prime}\right)$ obtained in the Atlantic and Mediterranean studies are shown.

and wider age ranges than males. These sexual differences in lengths and ages were reflected in the different growth parameters estimated. Studies of four-spot megrim in other areas also showed evidence of several of these variations in growth and differential mortality between sexes (Fuertes, 1978; Bello and Rizzi, 1987; Castilho et al., 1993; Santos, 1994; Landa et al., 2002; Teixeira et al., 2010; Cengiz et al., 2013), the possible reasons for the differences in this species being discussed in Landa et al. (2002) and Cengiz et al. (2013).

The inter-annual growth parameters obtained here offer an overview of the average growth of four-spot megrim in the Porcupine Bank in recent years. Thus, the parameters obtained here from direct age estimates cover an inter-annual growth variability of 5 years (2008-12). The estimates from back-calculation include, in addition to the variability of the 2 years of the samples (2011-12), that inherent to the years corresponding to each back-calculated age (e.g. a 4-year otolith captured in 2011, gives information of back-calculated lengths from 2008-age 1 to 2011-age 4). In this way, the growth parameters obtained from the length-ages calculated by both methods together (direct age estimation and back-calculation) include a wider inter-annual growth variability.

For combined sexes the growth performance indices $\left(\Phi^{\prime}\right)$ here obtained match the 2.50 value reported in the, to our knowledge, only existing study on four-spot megrim for this stock 7.b-k, 8.a,b,d (Robson et al., 2000) (Table 4), conducted on the nearby Irish continental shelf (Div. 7.b) and based on a limited number of samples (150 otoliths) dated 20 years ago (1997-99). The samples included in our study represent almost the whole range of catchable sizes and offer $L_{\infty}$ values (44-56 $\mathrm{cm})$ close to the largest size observed during surveys in the study area a)

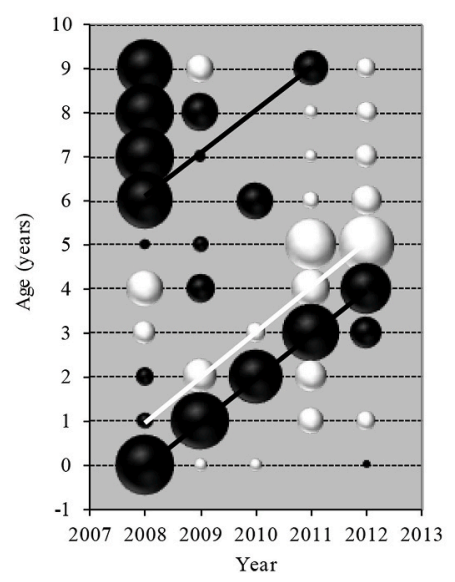

b)

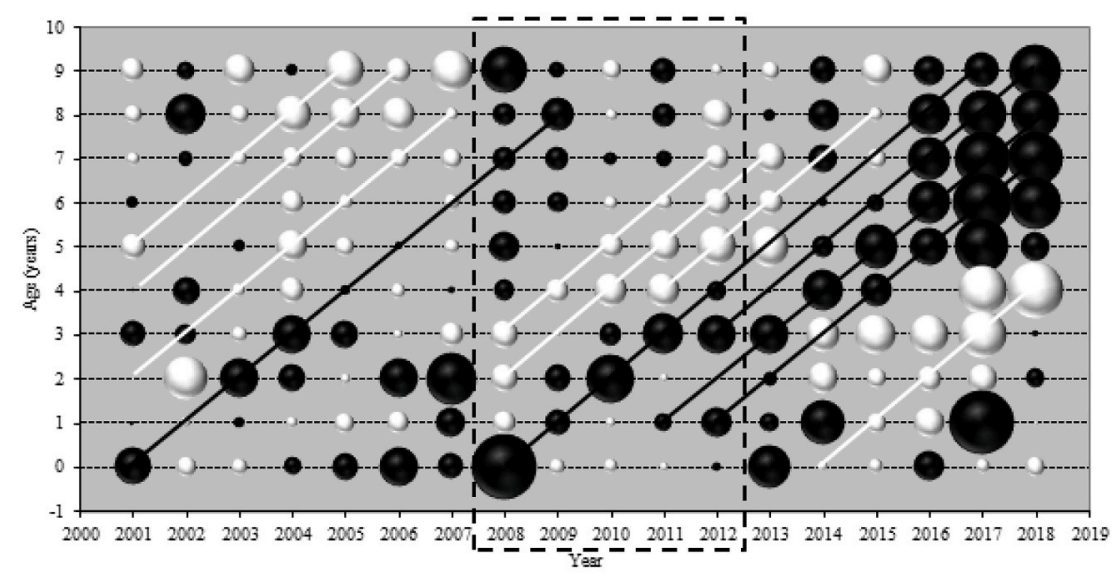

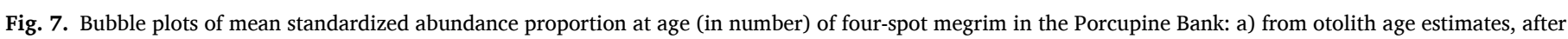

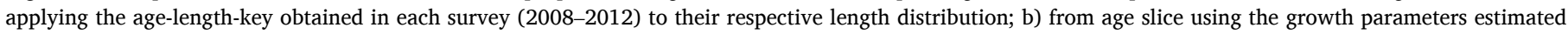

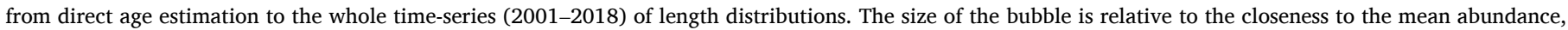

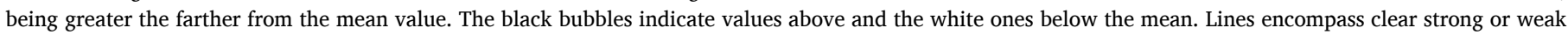
year-classes. The framework in bubble plot (b) includes the years 2008-11, in common with bubble plot (a), to facilitate comparison between both figures. 
(54 cm). ICES (WGBIE) requires updated growth information for the oncoming age-structured assessment of the state of this stock. The parameters here obtained can be used for the first age-structured assessment of the stock 7.b-k, 8.a,b,d, until more updated information on growth patterns in other areas is available. The corroboration of the growth pattern studied by cohort tracking offers a guarantee of accuracy for use in stock assessment. The growth parameters obtained here from direct age estimation and back-calculation together are based on a wide collection of 3602 length-age values. When comparing the parameters obtained here for combined sexes with those of the southern neighboring stock 8.c, 9.a, in northern Iberian waters, we observed that their $\Phi$ ' values ranged between 2.33 and 2.50 (Table 4, Fig. 6). The study of that stock based on a 23-year time-series, a significantly larger sample size ( $\sim 12,000$ age estimates) and a corroborated growth pattern (Landa and Fontenla, 2016), also showed growth parameters similar to those obtained here for the Porcupine Bank. Regarding the parameters for combined sexes in other areas of the distribution of four-spot megrim, its geographical variability was discussed by Landa and Fontenla (2016).

We ignore whether there is any other published study on four-spot megrim growth in the 7.b-k, 8.a,b,d stock presenting growth parameters of both sexes combined, that can be properly applied to the sizes (without sexing) of the catches for the assessment of the stock. Two previous studies [Dawson (1991) and Landa et al. (2002), in the Celtic Sea (7.h,j) and northern Bay of $\operatorname{Biscay(8.a,b),~respectively]~estimated~}$ growth parameters by sex but without including information on sexes combined and based on samples taken more than two decades ago (1990-92) (Appendix Table A).

Regarding $\Phi$ ' indices by sex from several European studies, those from Central and Eastern Mediterranean Sea present the lowest values $(\sim 2.2$ in males and $\sim 2.3$ in females) (Bello and Rizzi, 1987; Vassilopoulou and Ondrias, 1999; Cengiz et al., 2013). Higher values were found in Atlantic waters, the highest $\Phi^{`}$ to date being found in Galician waters (northern-8.c.1 and western-9.a.2) in both sexes (Fig. 8)(Fuertes, 1978; Landa et al., 2002). Our $\Phi$ ' values of $\sim 2.40$ in males and $\sim 2.53$ in females in the Porcupine Bank (7.b,c,k), are between those of the north

a)

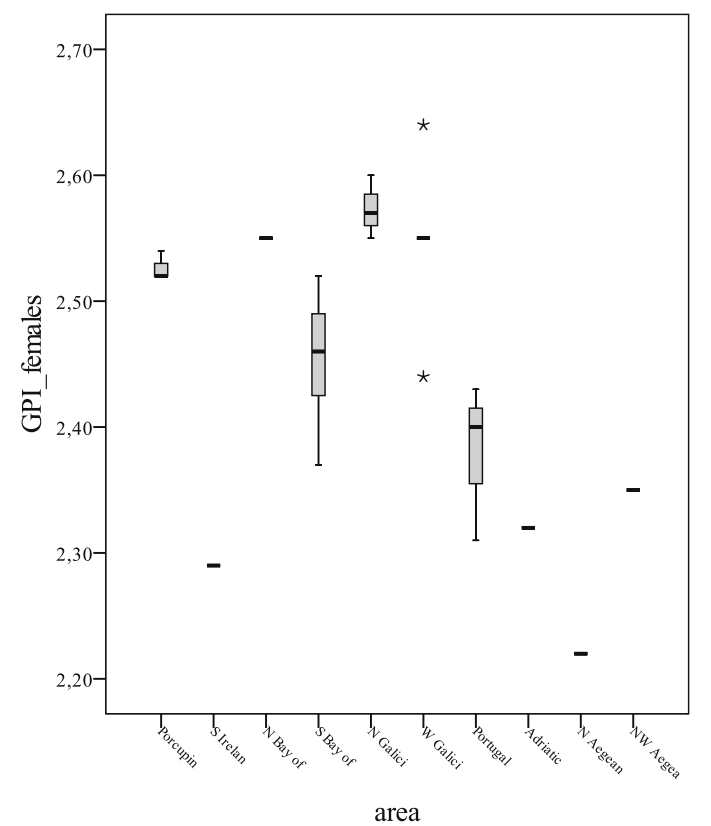

(8.a,b) and south (8.c.2) Bay of Biscay (Alperi, 1990; Pereda et al., 1998; Landa et al., 2002). The $\Phi$ ' indices in Portuguese waters (9.a.1) show lower values $(\sim 2.33$ in males and $\sim 2.38$ in females)(Castilho et al., 1993; Santos, 1994; Teixeira et al., 2010) but it is noticeable that the lowest $\Phi$ ' values in Atlantic waters were obtained in a preliminary study in the Celtic Sea-south Ireland (7.h,j) by Dawson (1991) (Fig. 8). The growth parameters of four-spot megrim in the present study showed medium-high values of $\mathrm{L}_{\infty}$ and medium-low values of $\mathrm{k}$ in both sexes, compared to the parameters estimated previously in other areas (Appendix Table A). Landa et al. (2002) and Cengiz et al. (2013) described the geographic variability of growth by sex in four-spot megrim in more detail. When comparing the growth of a species, it is advisable to take into account the sampling size, fish length range and time-series analyzed in each study, as well as if the age estimation is validated or corroborated. Thus, with respect to the 7.b-k, 8.a,b,d stock studied here, there is only one growth study by sex for each of the 7.h,j and 8.a,b areas (Dawson, 1991 and Landa et al., 2002, respectively), both with some sample limitations. Therefore, new parameter estimations are required in these areas to verify the curious different growth performance indices obtained between both nearby areas in those studies.

\subsection{Tracking cohorts}

Variations in the strength of the year-classes and density-dependence phenomena influence the interannual growth variability of this species (Landa, 1999). Therefore, in order to be able to carry out an adequate oncoming assessment of the state of this 7.b-k, 8.a,b,d stock, it is most advisable to have annual growth information (i.e., ALKs) obtained with a validated/corroborated age estimation criterion and calibrated among stock age (otolith) readers. Another option will be to use the synthetic growth parameters of several years presented here in the stock assessment. The slicing technique using growth parameters showed that tracking the more outstandingly strong cohort (i.e., 2008) (Fig. 7b) was not as clear in the 18-year time-series (2001-18) standardized Abundance proportions at Age (AaA) matrix as in the 5-year matrix obtained

b)

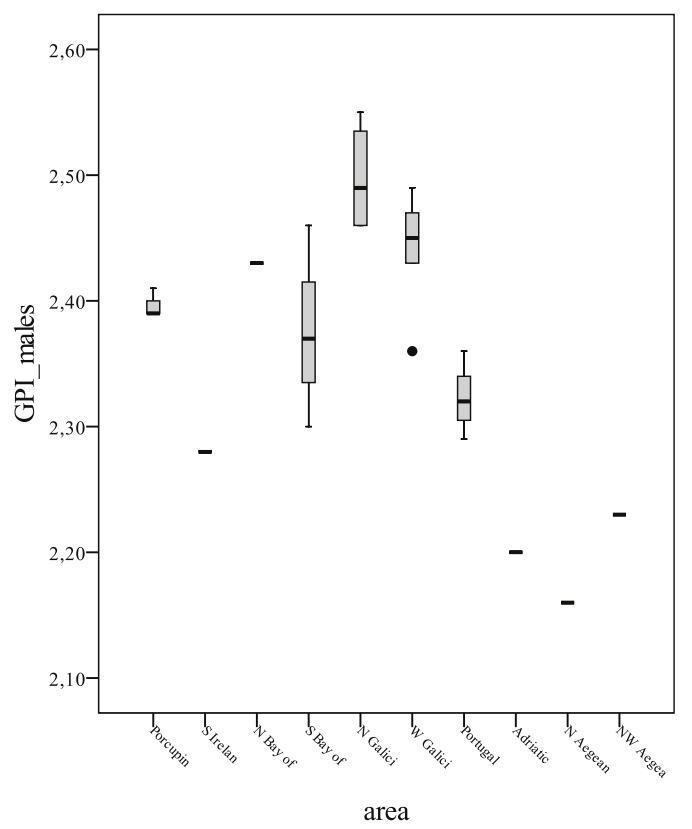

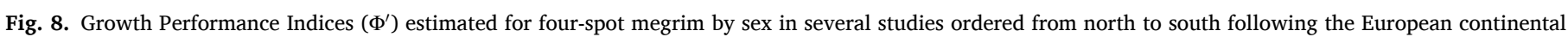

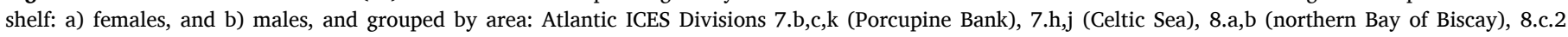

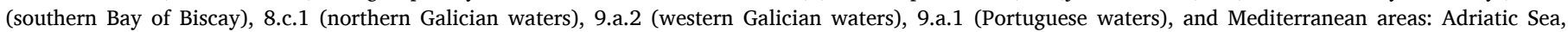
northern Aegean Sea and northwestern Aegean Sea. 
from direct age estimation (Fig. 7a). However, the former matrix (Fig. 7b) allows obtaining an image of the demographic structure of the catches of a long time-series such as the one studied here.

The progression or tracking of year-classes is considered as a method of corroboration or indirect validation of age determination (Campana, 2001; Panfili et al., 2002; ICES, 2011). Thus, tracking one or several extremely strong or weak cohorts during several years indicates whether the age interpretation criterion is accurate (Panfili et al., 2002). Corroborating the age estimation criteria in the 7.b-k, 8.a,b,d (Celtic Sea, west of Ireland, and northern Bay of Biscay) area by tracking the strong 2008 cohort is an important first step towards an accurate knowledge of the population structure of this stock. The bubble AaA matrix indicates possible weak recruitments in recent years (2014, 2015). The cohort of 2016 seems to be the strongest one of the 2014-2018 period and could balance the lower overall abundances resulting from those weak cohorts around 2016. The future knowledge of the AaA in years after 2012 based on age estimates may allow tracking the incipient 2016 cohort and others in subsequent years and older ages. This tracking cohort method has also corroborated the growth patterns estimated in otoliths of several populations, such as the 8.c, 9.a stock of four-spot megrim and its congener megrim (Landa and Fontenla, 2016; Landa et al., 2019), or in other species (eg. horse mackerel by Abaunza et al., 2003).

Our results also show the usefulness of this type of surveys, belonging to the ICES IBTS (ICES, 2010a), and specifically of this type of fishing gear (otter trawl gear "baca $40 / 52^{\prime \prime}$ ), to monitor the demographic structure, recruitments and cohort dynamics of four-spot megrim.

Knowing whether the population dynamics of a particular stock has similarities or differences with others is of interest for the identification of stocks and for fisheries management. The sign and strength of the cohorts here obtained, belonging to the stock in 7.b-k, 8.a,b,d, were compared with those obtained in a previous four-spot megrim study (Landa and Fontenla, 2016) from a southern area (northern Iberian waters, belonging to the 8.c, 9.a stock) and based on direct age readings using the same age estimation criterion used here. Cohorts of the common time-series of both studies (up to 2012) were compared, allowing us to analyze whether the most prominent cohorts were common for both stocks.

- On the one hand, the 2008-12 time-series based on direct age readings analyzed here (Fig. 7a) showed the very abundant 2008 cohort and the scarce 2007 cohort. However, in stock 8.c, 9.a, the strength of the 2008 cohort was slightly below average, as opposed to that of 2009, which was a strong cohort (Landa and Fontenla, 2016). Therefore, despite the short time-series compared ( 5 years) there are no clear similarities between the two stocks with respect to those significantly remarkable cohorts.

- On the other hand, the 2001-18 time-series (Fig. 7b), estimated here by slicing from the growth parameters of the 2008-12 period, was also compared with that of the 8.c, 9.a stock. Although the robustness of the cohorts analyzed was not as evident as in the aforementioned 2008-12 series based on the direct age readings of each year, this comparison allowed analyzing a larger time-series (12 years in common between both series). The matrix in stock 8.c, 9.a showed four remarkable cohorts in the common period analyzed, two strong ones in 2005 and 2009, and two weak ones in 1998 and 2001 (Landa and Fontenla, 2016). The strength of those cohorts also showed no similarity with those obtained in the present work, where the 2001, 2008-11 cohorts were remarkably abundant, as opposed to those of 2000, 2005 and 2006, that were weak.
These differences between stocks in demographic structure, cohort dynamics and recruitment signs demonstrate the utility of obtaining specific age estimates and growth parameters for each area and stock that are applicable to the respective catches of each area. The improvement in the accuracy of the demographic structure provided for the stock assessment process will contribute to more realistic stock status evaluations for a proper population management.

Only a few studies on essential biological parameters (e.g. abundance, distribution, age, growth or maturity) of other exploited fish in the Porcupine Bank have been published, mainly in the last two decades (e.g. bluemouth rockfish Helicolenus d. dactylopterus, Kelly et al., 1999; blue whiting Micromesistius poutassou, Kloppmann et al., 2001; squalid shark Deania calceus, Clarke et al., 2002; deepwater shark Centrophorus squamosus, Clarke et al., 2005; orange roughy Hoplostethus atlanticus, Minto and Nolan, 2006; anglerfish Lophius piscatorius, Velasco et al., 2008, Landa et al., 2013). More studies on life history parameters of the different species inhabiting the Porcupine Bank would contribute to a better knowledge of their relevance in the functioning of the ecosystem of this Bank, thus enhancing an ecosystem perspective management of this area.

To conclude, our findings, based on a broad sampling period of 5 years, constitute a step forward for an age-structured assessment of the state of the four-spot megrim Celtic Seas and northern Bay of Biscay stock and its catch predictions, thereby facilitating a sustainable stock management. Besides, at a species level, the new information presented here allows a broader knowledge of biological aspects and population dynamics of four-spot megrim, specifically its demographic structure, in one of the northernmost areas of its distribution, ultimately enabling a better global conservation of this commercial flatfish.

\section{CRediT authorship contribution statement}

Jorge Landa: Conceptualization, Methodology, Validation, Formal analysis, Investigation, Resources, Writing - original draft, Writing review \& editing, Visualization, Supervision, Project administration, Funding acquisition. Carmen Hernández: Methodology, Software, Validation, Formal analysis, Investigation, Resources, Data curation, Writing - original draft, Writing - review \& editing, Visualization.

\section{Declaration of competing interest}

The authors declare that they have no known competing financial interests or personal relationships that could have appeared to influence the work reported in this paper.

\section{Acknowledgements}

We thank F. Velasco, F. Baldó, V. Pita, C. Farias, M. Quinzán, J. Santos, F. Fernández and V. Duque for their collaboration during the "Porcupine" survey time-series (ERDEM project), the scientific teams of IEO, Marine Institute, and AZTI that made the sampling surveys possible, and the crews of research vessel "Vizconde de Eza". We also thank F. Velasco for his assistance with Fig. 1, and the two anonymous reviewers for their valuable critical remarks on the manuscript. The Spanish surveys on the Porcupine Bank are supported by the Instituto Español de Oceanografía and by the Data Collection Framework for the EU Common Fisheries Policy (European Maritime and Fisheries Fund). 
Appendix

Table A

Von Bertalanffy growth parameters, growth performance index and number of ages estimated by direct ageing and back-calculation in the present (in bold) and previous studies of four-spot mergim by sex.

\begin{tabular}{|c|c|c|c|c|c|c|c|c|c|c|c|c|c|c|c|c|}
\hline \multirow[t]{2}{*}{ Ocean/Sea } & \multirow[t]{2}{*}{ Stock } & \multirow[t]{2}{*}{ Area } & \multirow{2}{*}{$\begin{array}{c}\text { ICES } \\
\text { Division }\end{array}$} & \multirow[t]{2}{*}{ Author } & \multirow{2}{*}{$\begin{array}{l}\text { Data } \\
\text { year }\end{array}$} & \multirow[t]{2}{*}{ Methodology } & \multicolumn{5}{|c|}{ Males } & \multicolumn{5}{|c|}{ Females } \\
\hline & & & & & & & $\mathrm{L}_{\infty}$ & $\mathrm{k}$ & $\mathrm{t}_{0}$ & $\mathrm{n}$ & $\phi '$ & $\mathrm{~L}_{\infty}$ & $\mathrm{k}$ & $t_{0}$ & $\mathrm{n}$ & $\phi$, \\
\hline \multirow[t]{14}{*}{ Atlantic } & \multirow{5}{*}{$\begin{array}{l}\text { 7.b- } \\
\text { k, } 8 . \\
\text { abd }\end{array}$} & \multirow[t]{3}{*}{$\begin{array}{c}\text { Porcupine } \\
\text { Bank }\end{array}$} & \multirow[t]{3}{*}{ 7.b,c,k } & \multirow[t]{3}{*}{ Present study } & 2008-12 & $\begin{array}{l}\text { Direct age } \\
\text { estimation }\end{array}$ & 39.96 & 0.15 & -0.17 & 455 & 2.39 & 51.85 & 0.13 & 0.11 & 879 & 2.54 \\
\hline & & & & & 2011-12 & $\begin{array}{c}\text { Back- } \\
\text { calculation } \\
\text { (BPH) }\end{array}$ & 35.95 & 0.20 & -0.15 & 615 & 2.41 & 44.50 & 0.17 & -0.12 & 1653 & 2.52 \\
\hline & & & & & 2008-12 & $\begin{array}{c}\text { Direct age } \\
\text { estimation \& } \\
\text { back- } \\
\text { calculation } \\
\text { (BPH) }\end{array}$ & 37.61 & 0.17 & -0.29 & 1070 & 2.38 & 49.10 & 0.14 & -0.21 & 2532 & 2.52 \\
\hline & & $\begin{array}{l}\text { Southern } \\
\text { Ireland }\end{array}$ & 7.h, & Dawson (1991) & 1990 & $\begin{array}{l}\text { Direct age } \\
\text { estimation }\end{array}$ & 30.91 & 0.20 & -2.32 & 46 & 2.28 & 38.71 & 0.13 & -3.33 & 56 & 2.29 \\
\hline & & $\begin{array}{l}\text { North Bay } \\
\text { of Biscay }\end{array}$ & 8.a,b & $\begin{array}{l}\text { Landa et al. } \\
\text { (2002) }\end{array}$ & 1992 & $\begin{array}{l}\text { Direct age } \\
\text { estimation }\end{array}$ & 39.90 & 0.17 & -0.37 & 85 & 2.43 & 45.60 & 0.17 & 0.07 & 173 & 2.55 \\
\hline & \multirow[t]{9}{*}{$\begin{array}{l}\text { 8.c, } \\
\text { 9.a }\end{array}$} & $\begin{array}{l}\text { South Bay } \\
\text { of Biscay }\end{array}$ & 8.c2 & Alperi (1990) & $1983-84$ & $\begin{array}{l}\text { Direct age } \\
\text { estimation }\end{array}$ & $30.64-34.77$ & $0.18-0.23$ & $\begin{array}{l}(-1.53)- \\
(-1.37)\end{array}$ & 160 & 2.34 & $39.88-45.28$ & $0.12-0.18$ & $\begin{array}{l}(-1.72)- \\
(-1.54)\end{array}$ & 196 & 2.42 \\
\hline & & & & Alperi (1991) & 1990 & $\begin{array}{l}\text { Direct age } \\
\text { estimation }\end{array}$ & 37.73 & 0.14 & -2.20 & 162 & 2.30 & 44.39 & 0.12 & -2.18 & 223 & 2.37 \\
\hline & & & & $\begin{array}{l}\text { Landa et al. } \\
\text { (2002) }\end{array}$ & 1991-94 & $\begin{array}{l}\text { Direct age } \\
\text { estimation }\end{array}$ & 37.05 & $0.17-0.21$ & $\begin{array}{l}(-0.27)- \\
(-0.81)\end{array}$ & 655 & $2.37-2.46$ & 45.60 & $0.14-0.16$ & $\begin{array}{l}(-0.21)- \\
(-0.89)\end{array}$ & 908 & $2.46-2.52$ \\
\hline & & $\begin{array}{c}\text { North } \\
\text { Galicia (NW } \\
\text { Iberian P.) }\end{array}$ & 8.c1 & $\begin{array}{l}\text { Landa et al. } \\
\quad(2002)\end{array}$ & 1991-94 & $\begin{array}{l}\text { Direct age } \\
\text { estimation }\end{array}$ & 37.05 & $0.21-0.26$ & $\begin{array}{l}(-0.47)- \\
(-0.14)\end{array}$ & 543 & $2.46-2.55$ & 45.60 & $0.17-0.19$ & $\begin{array}{l}(-0.63)- \\
(-0.32)\end{array}$ & 838 & $2.55-2.60$ \\
\hline & & $\begin{array}{c}\text { West } \\
\text { Galicia (NW }\end{array}$ & $9 . a 2$ & Fuertes (1978) & 1975 & $\begin{array}{l}\text { Direct age } \\
\text { estimation }\end{array}$ & 34.71 & 0.19 & -1.37 & 183 & 2.36 & 42.88 & 0.15 & -1.36 & 197 & 2.44 \\
\hline & & Iberian P.) & & $\begin{array}{l}\text { Landa et al. } \\
\text { (2002) }\end{array}$ & 1991-94 & $\begin{array}{l}\text { Direct age } \\
\text { estimation }\end{array}$ & 35.15 & $0.22-0.25$ & $\begin{array}{l}(-0.39)- \\
(-0.15)\end{array}$ & 412 & $2.43-2.49$ & 45.60 & $0.17-0.21$ & $\begin{array}{l}(-0.61)- \\
(-0.18)\end{array}$ & 679 & $2.55-2.64$ \\
\hline & & $\begin{array}{l}\text { Portuguese } \\
\text { waters }\end{array}$ & 9.a1 & $\begin{array}{l}\text { Castilho et al. } \\
\text { (1993) }\end{array}$ & $1985-86$ & $\begin{array}{l}\text { Direct age } \\
\text { estimation }\end{array}$ & 37.50 & 0.14 & -1.93 & 315 & 2.29 & 44.00 & 0.14 & -1.52 & 250 & 2.43 \\
\hline & & & & Santos (1994) & 1989-92 & $\begin{array}{l}\text { Direct age } \\
\text { estimation }\end{array}$ & 34.79 & 0.20 & -1.44 & 217 & 2.36 & 39.77 & 0.16 & -1.86 & 227 & 2.40 \\
\hline & & & & $\begin{array}{l}\text { Teixeira et al. } \\
(2010)\end{array}$ & 2003-05 & $\begin{array}{l}\text { Direct age } \\
\text { estimation }\end{array}$ & 32.37 & 0.20 & -2.49 & 103 & 2.32 & 38.11 & 0.14 & -2.85 & 199 & 2.31 \\
\hline \multirow[t]{3}{*}{$\begin{array}{l}\text { Mediterranean } \\
\text { Sea }\end{array}$} & & $\begin{array}{c}\text { Sothwest } \\
\text { Adriatic Sea }\end{array}$ & - & $\begin{array}{l}\text { Bello and Rizzi } \\
\text { (1987) }\end{array}$ & 1986 & $\begin{array}{l}\text { Direct age } \\
\text { estimation }\end{array}$ & 27.60 & 0.21 & -1.27 & 82 & 2.20 & 28.50 & 0.26 & -0.85 & 55 & 2.32 \\
\hline & & $\begin{array}{c}\text { North } \\
\text { Aegean Sea }\end{array}$ & - & $\begin{array}{l}\text { Vassilopoulou } \\
\text { and Ondrias } \\
\text { (1999) }\end{array}$ & $1990-92$ & $\begin{array}{c}\text { Back- } \\
\text { calculation }\end{array}$ & 25.50 & 0.22 & -1.09 & 923 & 2.16 & 30.50 & 0.18 & -1.10 & 1241 & 2.22 \\
\hline & & $\begin{array}{l}\text { Northwest } \\
\text { Aegean Sea }\end{array}$ & - & $\begin{array}{c}\text { Cengiz et al. } \\
\text { (2013) }\end{array}$ & $2006-08$ & $\begin{array}{l}\text { Direct age } \\
\text { estimation }\end{array}$ & 39.10 & 0.11 & -2.59 & 235 & 2.23 & 49.80 & 0.09 & -2.15 & 553 & 2.35 \\
\hline
\end{tabular}




\section{References}

Abaunza, P., Gordo, L., Karlou-Riga, C., Murta, A., Eltink, A., Santamaria, M.T.G., Zimmermann, C., Hammer, C., Lucio, P., Iversen, S.A., Molloy, J., Gallo, E., 2003. Growth and reproduction of horse mackerel, Trachurus trachurus (Carangidae). Rev. Fish Biol. Fish. 13 (1), 27-61.

Alperi, J., 1990. Croissance des cardines (Lepidorhombus whiffiagonis et L. boscii) en Mer Cantabrique (Division VIIIc du CIEM), vol. 20. ICES CM 1990/G, p. 16.

Alperi, J., 1991. Population parameters of megrims (Lepidorhombus whiffiagonis and L. boscii) in the cantabrian Sea (VIIIc ICES division). In: Working Document for the ICES Hake. Megrim and Monk Working Group, p. 11.

Anon, 1997. Report of Workshop on Megrim Otolith and Fin Rays Age Reading. IEO, Vigo, Spain, p. 47.

Beare, D., Castro, J., Cotter, J., van Keeken, O., Kell, L., Laurec, A., Mahé, J.C., et al., 2003. Final Report: Evaluation of Research Surveys in Relation to Management Advice (EVARES) UE DG FISH/2001/02).

Bello, G., Rizzi, E., 1987. On the growth of the four-spotted scaldfish, Lepidorhombus boscii, from the Southern Adriatic. FAO Fish. Rep. 394, 142-146.

Campana, S.E., 2001. Accuracy, precision and quality control in age determination, including a review of the use and abuse of age validation methods. J. Fish. Biol. 59, $197-242$

Casselman, J.M., 1987. Determination of age and growth. In: A.H, Gill, H.S. (Eds.), The Biology of Fish Growth (Weatherley. Academic Press, New York, pp. 209-242.

Castilho, R., Dinis, M.T., Erzini, K., 1993. Age and growth of megrim Lepidorhombus boscii (Risso) of the Portuguese continental coast. Fish. Res. 16, 339-346.

Cengiz, O., Ozekinci, U., Ismen, A., Oztekin, A., 2013. Age and growth of the four-spotted megrim (Lepidorhombus boscii risso, 1810) from saros Bay (northern Aegean Sea, Turkey). Mediterr. Mar. Sci. 14 (1), 36-44.

Clarke, M.W., Connolly, P.L., Bracken, J.J., 2002. Catch, discarding, age estimation, growth and maturity of the squalid shark Deania calceus west and north of Ireland. Fish. Res. 56 (2), 139-153.

Clarke, M.W., Connolly, P.L., Bracken, J.J., 2005. Age estimation of the exploited deepwater shark Centrophorus squamosus from the continental slopes of the Rockall Trough and Porcupine Bank. J. Fish. Biol. 60, 501-514.

Dawson, W.A., 1991. Preliminary study of the age and growth of megrim (Lepidorhombus whiffiagonis) and four spot megrim (Lepidorhombus boscii) from the Celtic Sea, (ICES division VII). In: Working Document for the Hake. Megrim and Monk ICES Working Group (WGHMM), p. 18 .

Egan, A., Etherton, M., Gomez de Segura, A., Iriondo, A., Marcal, A., Power, I., Quincoces, I., Santurtun, M., Vingaard Larsen, P., Warne, S., 2004. Workshop on Megrim Otolith Age Readings. AZTI, Sukarrieta, Spain, p. 27.

Etherton, M., 2011. Report of the International Age Determination Exchange of Megrim Otoliths, 2010. CEFAS, Lowestoft, UK, p. 24.

Francis, R., 1990. Back-calculation of fish length: a critical review. J. Fish. Biol. 36 (6), 883-902.

Fraser, C.McL., 1916. Growth of the spring salmon. Trans Pacif Fish Soc 1915, 29-39.

Fuertes, J.R., 1978. Edad y crecimiento del gallo (Lepidorhombus boscii, Risso) en el litoral gallego. Investig. Pesq. 42 (2), 241-253.

Gault, M., 2019. Megrim (Lepidorhombus whiffiagonis) otolith exchange 2018. In: Working Document to the Working Group on Biological Parameters (WGBIOP). Lisbon, Portugal, pp. 7-10. October 2019.

ICES, 2010a. Report of the International Bottom Trawl Survey Working Group (IBTSWG). 22-26 March 2010 Lisbon, Portugal. ICES CM 2010/SSGESST:06, p. 261.

ICES, 2010b. Addendum 2: IBTS manual on the western and southern areas 2010. In: Revision III. Agreed during the Meeting of the International Bottom Trawl Survey Working Group 22-26 March 2010, Lisbon, Portugal, p. 58.

ICES, 2011. Report of the Workshop of National Age Readings Coordinators (WKNARC) 5-9 September 2011, Boulogne-Sur-Mer, France, vol. 45. ICES CM 2011/ACOM, p. 175.

ICES, 2018. Report of the Working Group for the Bay of Biscay and the Iberian Waters Ecoregion (WGBIE), 3-10 May 2018, ICES HQ, Copenhagen, Denmark, vol. 12. ICES CM 2018/ACOM, p. 642.

ICES, 2019. Report of the working group for the Bay of Biscay and the iberian waters ecoregion (WGBIE). ICES Scientific Reports 1 (31), 692. https://doi.org/10.17895/ ices.pub.5299.

Kelly, C.J., Connolly, P.L., Bracken, J.J., 1999. Age estimation, growth, maturity, and distribution of the bluemouth rockfish Helicolenus d. dactylopterus (Delaroche 1809) from the Rockall Trough. ICES (Int. Counc. Explor. Sea) J. Mar. Sci. 56 (1), 61-74.
Kingsley, M.C.S., Kanneworff, P., Carlsson, D.M., 2004. Buffered random sampling: a sequential inhibited spatial point process applied to sampling in a trawl survey for northern shrimp Pandalus borealis in West Greenland waters. ICES (Int. Counc. Explor. Sea) J. Mar. Sci. 61, 12-24.

Kirkwood, G.P., Aukland, R., Zara, S.J., 2001. Length Frequency Distribution Analysis (LFDA), Version 5.0. MRAG Ltd, London, UK.

Kloppmann, M., Mohn, C., Bartsch, J., 2001. The distribution of blue whiting eggs and larvae on Porcupine Bank in relation to hydrography and currents. Fish. Res. 50 (12), 89-109.

Landa, J., 1999. Density-dependent growth of four spot megrim (L. boscii) in the northern Spanish shelf. Fish. Res. 40, 267-276.

Landa, J., Antolínez, A., Barrado, J., Fontenla, J., Hernández, C., Villamor, B., Dueñas, C., Navarro, M.R., 2014. Age determination procedures for benthic fish in Spanish Institute of Oceanography (IEO). Int. Doc. IEO. 34. http://hdl.handle.net/10508/1 744.

Landa, J., Barrado, J., Velasco, F., 2013. Age and growth of anglerfish (Lophius piscatorius) on the Porcupine Bank (west of Ireland) based on illicia age estimation. Fish. Res. 137, 30-40.

Landa, J., Fontenla, J., 2016. Age and growth of four spot megrim (Lepidorhombus boscii) in northern Iberian waters corroborated by cohort tracking. Estuar. Coast Shelf Sci. $179,181-188$

Landa, J., Fontenla, J., Rodríguez-Marín, E., 2019. Corroboration of age estimation of megrim (Lepidorhombus whiffiagonis) in northern Iberian waters by cohort tracking. Continent. Shelf Res. 183, 1-13.

Landa, J., Pérez, N., Piñeiro, C., 2002. Growth patterns of the four spot megrim (Lepidorhombus boscii) in the northeast Atlantic. Fish. Res. 55, 141-152.

Lee, R.M., 1920. A review of the methods of age and growth determination by means of scales. Fishery Invest., Lond., Ser. 24 (2), 32.

Minto, C., Nolan, C.P., 2006. Fecundity and maturity of orange roughy (Hoplostethus atlanticus collett 1889) on the Porcupine Bank, northeast atlantic. Environ. Biol. Fish. 77, 39-50.

Mohn, C., Bartsch, J., Meincke, J., 2002. Observations of the mass and flow field at Porcupine Bank. ICES (Int. Counc. Explor. Sea) J. Mar. Sci. 59, 380-392.

Panfili, J., de Pontual, H., Troadec, H., Wright, P.J., 2002. Manual of Fish Sclerochronology. IFREMER-IRD co-edition, Brest, p. 464.

Pauly, D., 1994. A framework for latitudinal comparisons of flatfish recruitment. Neth. J. Sea Res. 32 (2), 107-118.

Pauly, D., Munro, J.L., 1984. Once more on growth comparison in fish and invertebrates. ICLARM Fishbyte 2 (1), 21.

Pereda, P., Afonso, M.H., Azevedo, M., Dawson, W., Duarte, R., Dupouy, H., Franco, J., Godinho, M.L., Landa, J., Loureiro, I., Lucio, P., Macara, H., Mahé, J.C., Pérez, N. Piñeiro, C., Saínza, M., Santurtún, M., Trujillo, V., 1998. Final Report: "Biological Studies of Demersal Fish (BIOSDEF)" UE DG XIV 95/038.

Ricker, W.E., 1992. Back-calculation of fish lengths based on proportionality between scale and length increments. Can. J. Fish. Aquat. Sci. 49 (5), 1018-1026.

Robson, M.S., King, P.A., Hannan, J., Mcgrath, D., 2000. Age and growth of a sample of four-spot megrim, Lepidorhombus boscii, from off the west coast of Ireland. Biol. Environ. 100B (3), 143-148.

Santos, P., 1994. Growth and reproduction of the population of the four-spot megrim (Lepidorhombus boscii Risso) off the Portuguese coast. Neth. J. Sea Res. 32 (3-4), 379-383.

Teixeira, C.M., Batista, M.I., Cabral, H.N., 2010. Diet, growth and reproduction of four flatfishes on the Portuguese coast. Sci. Mar. 74 (2), 223-233.

Vassilopoulou, V., Ondrias, I., 1999. Age and growth of the four-spotted megrim (Lepidorhombus boscii) in eastern Mediterranean waters. J. Mar. Biol. Assoc. U. K. 79, $171-178$.

Velasco, F., Landa, J., Barrado, J., Blanco, M., 2008. Distribution, abundance, and growth of anglerfish (Lophius piscatorius) on the Porcupine Bank (west of Ireland) ICES (Int. Counc. Explor. Sea) J. Mar. Sci. 65 (7), 1316-1325.

von Bertalanffy, L., 1938. A quantitative theory of organic growth (inquiries on growth laws II). Hum. Biol. 10, 181-213.

White, M., Mohn, C., Orren, M., 1998. Nutrient distributions across the Porcupine Bank. ICES (Int. Counc. Explor. Sea) J. Mar. Sci. 55, 1082-1094.

Whitehead, P.J., Bauchot, M.L., Hureau, J.C., Nielsen, J., Tortonesse, E., 1986. Fishes of the North-eastern Atlantic and the Mediterranean. UNESCO, París, p. 1362.

Whitney, R.R., Carlander, K.D., 1956. Interpretation of body-scale regression for computing body length of fish. J. Wildl. Manag. 20, 1-27. 